PONTIFÍCIA UNIVERSIDADE CATÓLICA DO RIO DE JANEIRO

A influência da inteligência emocional e social dos líderes sobre os liderados

Nicolle Brasil

Trabalho de Conclusão de Curso

CENTRO DE CIÊNCIAS SOCIAIS - CCS

DEPARTAMENTO DE ADMINISTRAÇÃO

Graduação em Administração de Empresas 


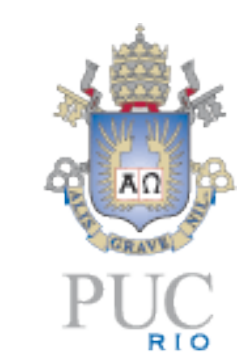

Nicolle Brasil

\section{A influência da inteligência emocional e social dos líderes sobre os liderados}

Trabalho de Conclusão de Curso

Trabalho de Conclusão de Curso, apresentado ao programa de graduação em Administração da PUC-Rio como requisito parcial para a obtenção do titulo de graduação em Administração.

Orientador : Patrícia Itala Ferreira

Rio de Janeiro

Junho de 2019. 


\section{Agradecimentos}

Meus agradecimentos vão à minha família por acreditarem em mim e estarem sempre ao meu lado, independente de qualquer circunstância. Aos meus amigos da vida, por me apoiarem, me ajudarem, me incentivarem sempre a ser uma pessoa melhor e por serem exatamente como são. Aos meus amigos da faculdade, por todos esses anos estarem ao meu lado dividindo tantos momentos especiais que a faculdade nos proporcionou. À minha orientadora, por ter toda paciência e dedicação para me ajudar, e por fim, a minha própria universidade, que além de todos os ensinamentos, me fez criar laços e histórias que eu vou levar para sempre comigo. 


\section{Resumo}

BRASIL, Nicolle. A influência da inteligência emocional e social entre líderes e liderados. Rio de Janeiro, 2019. 54 p. Trabalho de Conclusão de Curso - Departamento de Administração. Pontifícia Universidade Católica do Rio de Janeiro.

O estudo objetivou avaliar a influência da inteligência emocional e social dos líderes sobre os liderados. Para isso, foram realizadas pesquisas bibliográficas sobre liderança, inteligência emocional e social em livros e artigos. Além disso, foi realizada uma pesquisa de campo via aplicação de um questionário em 57 liderados da empresa Litografia Valença com o intuito de avaliar a percepção dessas inteligências e como elas podem influenciá-los. Como principais resultados obteve-se a comprovação do uso da inteligência emocional e social pelos líderes da empresa e sua influência a partir da percepção dos liderados que participaram do questionário.

Palavras-chave:

Liderança, Inteligência emocional, Inteligência social. 


\section{Abstract}

BRASIL, Nicolle. A influência da inteligência emocional e social entre líderes e liderados. Rio de Janeiro, 2019. 54 p. Trabalho de Conclusão de Curso - Departamento de Administração. Pontifícia Universidade Católica do Rio de Janeiro.

This research seeks to analyze the influence of emotional and social intelligence of leaders in relation to those they lead. In order to do so, a bibliographic research was made based on materials such as textbooks and articles. Moreover, a questionaire to subordinates of the company Litografia Valença was elaborated in order to evaluate their perception of emotional and social intelligence of their leaders and its influence on them. In this way, it was possible to make an analysis pointing to the importance of the use of both abilities by leaders of an organisation.

Key-words:

Lidership, Emotional intelligence, Social intelligence. 


\section{Sumário}

1 Tema e o problema de estudo 8

1.1. Introdução ao tema e ao problema do estudo 8

1.2. Objetivo do estudo 10

1.3. Objetivos intermediários 10

1.4. Delimitação e foco do estudo 10

$\begin{array}{ll}\text { 1.5. Justificativa e relevância do estudo } & 11\end{array}$

2 REFERENCIAL TEÓRICO 12

2.1. Liderança 12

2.1.1. Liderança: visão geral 12

2.1.2. A Estrutura de Valores Concorrentes 13

2.2. Inteligência emocional 17

2.3. Inteligência social 22

3 Métodos e procedimentos de coleta e de análise de dados do estudo 27

3.1. Método de Pesquisa Utilizado 27

3.2. Estrutura do Questionário e Coleta de dados 28

$\begin{array}{ll}3.3 \text { Limitações do estudo } & 29\end{array}$

4 Apresentação dos resultados 30

4.1. A empresa 30

4.2. Perfil dos pesquisados 30

4.3. Descrição e análise dos resultados 31

5 Conclusão 44

5.1 Recomendações para novos estudos 45

6 REFERÊNCIAS BIBLIOGRÁFICAS 46 


\section{Lista de tabelas}

Tabela 1 - Setores x quantidade de respondentes

28

\section{Lista de figuras}

Figuras 1 - Estrutura de Valores Concorrentes

14

Figuras 2 - Janela Johari

20

\section{Lista de gráficos}

Gráfico 1 - Faixa etária dos respondentes

Gráfico 2 - O seu líder é preocupado em manter a equipe motivada e um ambiente de trabalho saudável?

Gráfico 3 - O seu líder dá feedbacks construtivos?

Gráfico 4 - De 0 a 5 com que frequência você recebe feedbacks, pelo menos, mensalmente?

Gráfico 5 - De 0 a 5, qual é o nível de satisfação com os feedbacks 35 Gráfico 6 - Você se sente confortável em dar feedbacks ao seus líderes, dizendo o que te incomoda ou agrada e a forma como ele pode melhorar?

Gráfico 7 - O seu líder conhece seus próprios pontos fracos e procuram melhorá-los?

Gráfico 8 - Como você acha que os líderes lidam com os problemas do dia a dia?

Gráfico 9 - Seu líder é uma pessoa com empatia, ou seja, capaz de sentir e entender as emoções dos membros da equipe e procura ajudá-los? 40 Gráfico 10 - Qual é a capacidade do seu líder para gerir as pessoas? 41 Gráfico 11 - De 0 a 5, quanto você acredita que a forma como o líder interage com você interfere no seu dia a dia e desenvolvimento profissional? 


\section{Tema e o problema de estudo}

\subsection{Introdução ao tema e ao problema do estudo}

Segundo Junqueira, Couto e Pereira (2011), o homem está em constante contato com diversos tipos de informações. $\mathrm{O}$ estresse e a falta de tempo para lazer, por exemplo, vem impactando significativamente o dia a dia das pessoas. A partir disso, é possível verificar que torna-se cada vez mais necessário conhecer e administrar as emoções e a forma como elas impactam o ambiente externo para se obter uma melhor qualidade de vida.

As organizações, em contrapartida, também enfrentam com o desafio de lidar com as diferentes emoções, limitações e necessidades dos indivíduos que a compõem. Além dos conhecimentos técnicos relativos às funções, também são essenciais as habilidades emocionais e sociais para o alcance do sucesso organizacional. Segundo Quinn et al. (2015) é necessário que todos os membros da organização entendam a importância do controle das emoções e saibam identificar a melhor forma de expressa-lá, principalmente os líderes, que estão em constante contato com pessoas.

Os autores defendem que os líderes das organizações devem desenvolver sua equipe e oferecer oportunidades para envolvê-la com as metas da empresa. É preciso que eles ajudem os funcionários a reconhecerem sua importância na organização. Fornecer feedbacks agregadores, estimular diferentes habilidades de cada um, tentar equilibrar as necessidades individuais com as da unidade de trabalho e promover coesão entre os membros são exemplos de papéis importantes demandados dos líderes nos dias atuais. Boyatzis e Mckee (2005) complementam que, além de obterem resultados atrelados ao objetivo da empresa, os líderes devem ser motivadores para seus liderados e, para isso, é essencial a prática da inteligência emocional e social.

Ainda segundo Boyatzis e Mckee (2005, p. 27) “(...) a inteligência emocional e social representa $85 \%$ a $90 \%$ das diferenças entre os líderes de destaque e os demais”. Eles afirmam que, para ser um líder excelente, é necessário 
não apenas o desenvolvimento de seu intelecto, relacionado as complexidades e desafios que as organizações enfrentam, mas também a compreensão e o controle das emoções, o cuidado com o seu corpo e a busca dos sonhos e crenças.

Ainda segundo os autores, os líderes devem estar despertos e sintonizados consigo mesmo, com os demais e com o mundo ao seu redor. Para isso, devem ser emocionalmente inteligentes, lidando com a incerteza do mundo atual com esperança, e encarando os obstáculos e dificuldades como oportunidades. Além de ter consideração com os outros, mantendo a empatia e compaixão por todos ao seu redor.

Conclui-se que os líderes, para cumprirem sua tarefa de administração com êxito, devem, antes de liderar as pessoas, conhecer e administrar a si próprio. Esse desafio de autoconhecimento, segundo os autores, inclui primeiramente, a conexão de seus valores internos, dando significado as ações, e alinhando as emoções aos objetivos centrais.

Seguindo uma linha similar a dos autores Boyatzis e Mckee (2005), são diversos os estudos que reafirmam a importância da inteligência emocional e social dentro das empresas. Os líderes, enquanto gestores de pessoas, são pessoas que devem buscar desenvolver suas inteligências, focando tanto nos resultados como nas diferenças e peculiaridades de cada liderado para desenvolver as melhores habilidades de cada um.

Para melhor compreender a importância das inteligências emocional e social, esse estudo focou a empresa Litografia Valença, atuante no setor industrial de produção de embalagens metálicas. A empresa está inserida no mercado desde 1998, sendo considerada uma das três maiores do Brasil em seu setor. Atualmente conta com mais de 800 funcionários e é responsável por produzir e transportar embalagens metálicas para todo o país.

O estudo focará na empresa citada a fim de identificar como os liderados percebem seus líderes considerando a prática da inteligência emocional e social e como isso pode afetá-los. A inteligência emocional e social foi usada nessa empresa específica pois a autora do trabalho é parte da família que tem propriedade sobre ela e acredita que esses conceitos são importantes de serem abordados e colocados em prática, ou ao menos pesquisados, pela gestão atual. 


\subsection{Objetivo do estudo}

Esse trabalho tem como objetivo compreender a forma como a prática da inteligência emocional e social afeta a relação entre líderes e liderados da Litografia Valença.

\subsection{Objetivos intermediários}

Visando alcançar o objetivo central do estudo, os seguintes objetivos intermediários foram necessários:

- Compreender a importância de uma liderança eficaz dentro da organização e as competências gerenciais necessárias para que ela obtenha sucesso.

- Detalhar a importância dos líderes entenderem sobre si mesmos e os outros, e como a comunicação honesta e efetiva impacta na empresa.

- Descrever a importância da inteligência emocional no âmbito organizacional, principalmente para aqueles que lideram outros, exemplificando formas de exercitá-la.

- Apresentar a necessidade de estimular a inteligência social dentro da organização, assim como formas para o alcançá-la e seus benefícios.

- Investigar como os funcionários da empresa Litografia Valença percebem seus líderes, com foco nas inteligências emocional e social.

\subsection{Delimitação e foco do estudo}

O estudo propõe identificar como a inteligência emocional e social é vista pelos liderados da organização e se isso pode afetá-los ou não. Para isso, foi realizada uma pesquisa entre os funcionários da empresa Litografia Valença para obter sua percepção sobre seus líderes. O estudo teve como base os empregados 
que trabalham na cidade do Rio de Janeiro, visto que essa empresa se encontra em mais três outras cidades. Assim, o questionário elaborado visou estudar apenas a relação com determinados líderes dessa empresa. O estudo foi elaborado entre os meses de março e junho de 2019.

\subsection{Justificativa e relevância do estudo}

O resultado do estudo pode contribuir para estimular a reflexão dos líderes em relação à importância de controlar e lidar com as suas emoções, e de como eles podem interagir com as pessoas a partir delas. Eles poderão ter uma noção maior de como são vistos e compreendidos pelos seus liderados, o que pode proporcionar oportunidades de mudanças.

Além de ajudar os líderes a criar um ambiente de trabalho mais harmônico e saudável, o estudo também poderá beneficiar os próprios liderados, que encontrarão novas formas de se relacionar com os líderes a partir de seu amadurecimento nas inteligências foco do estudo.

Para a empresa foco do estudo, a pesquisa também poderá ser relevante ao indicar pontos positivos e oportunidades de melhoria na relação líder x liderados. Considerando a academia, o estudo pode ajudar a obter uma melhor compreensão sobre a prática da inteligência emocional e social por parte dos líderes e seu impacto nos liderados.

Para a autora, a pesquisa poderá contribuir para analisar a relação entre líderes e liderados da empresa que faz parte de sua vida e dos seus familiares. Obtendo assim, mais informações internas sobre ela que possam agregar no futuro da organização, como por exemplo para a criação de novas medidas de fazer com o que a empresa seja mais saudável, transparente e harmônica. 


\section{REFERENCIAL TEÓRICO}

Nesse capítulo são apresentados e discutidos conceitos que envolvem a forma como os líderes exercitam e utilizam suas inteligências emocional e social no âmbito laboral. Esta seção divide-se em três partes:

A primeira diz respeito ao conceito de liderança, sua importância e competências necessárias para impactar positivamente o ambiente organizacional.

A segunda é sobre a inteligência emocional, suas características, e competências necessárias para desenvolvê-la.

Já terceira aborda o conceito da competência social, sua importância na sociedade, e formas que contribuam para a sua melhoria.

\subsection{Liderança}

\subsubsection{Liderança: visão geral}

O conceito de liderança passou por algumas transformações ao longo do tempo, e vem sendo interpretado de diferentes maneiras em comparação ao que se entendia no passado. Silva et al. (2014) defendem que, antigamente, a liderança era baseada no poder, através da criação de disciplina, ordem e padrões pré definidos, que todos deveriam seguir. Já nos dias atuais, os autores defendem que além de representar capacidade, discernimento, flexibilidade e objetividade, o líder deve ser capaz de usar a autoridade para estar à frente, inspirando grupos e equipes dentro das organizações.

Seguindo a mesma linha, Hunter $(2004$, p. 25.) afirma que liderança é a “(...) habilidade de influenciar pessoas para trabalharem entusiasticamente visando atingir aos objetivos identificados como sendo para o bem comum". Portanto, em uma empresa, o líder deve ser responsável por incentivar e promover a coesão entre os membros da equipe. Cabe a ele manter sua equipe bem e em sinergia 
diante de imprevistos, deixando-a alinhada em busca de objetivos em comum com a organização.

Bittel (1982, p. 41) complementa que “(...) liderança é o artifício de fazer com que outras pessoas o sigam e façam voluntariamente aquilo que você deseja que façam". Diante disso, entende-se que o líder tem um papel fundamental na criação de um ambiente harmônico, além de ser responsável por entender as peculiaridades de cada liderado, sendo capaz de convencê-los a seguir os padrões de forma natural, aceitando novas sugestões e respeitando as diferenças.

Quinn et al. (2015) abordam outros desafios enfrentados pelos líderes das organizações modernas. Os autores acreditam que as empresas devem ser estáveis e controladas, com processos internos padronizados e eficientes, ao mesmo tempo que possuem estruturas adaptáveis e flexíveis, que possibilitem inovação e mudança, acompanhando o dinamismo da sociedade atual.

Os autores afirmam ainda que cada funcionário deve ser valorizado, respeitado e entendido como a peça mais importante dentro de uma organização, mas, ao mesmo tempo, deve seguir e cumprir metas e planos estabelecidos. Os interesses opostos dentro das organizações caminham juntos, ou seja, devem ser tratados como parte de um sistema integrado. Assim sendo, os autores defendem que a teoria da "Estrutura de Valores Concorrentes" é o modelo aconselhável para organizar a discussão sobre as diferentes competências centrais necessárias para uma gestão efetiva e competente, o que será detalhado na sequência.

\subsubsection{A Estrutura de Valores Concorrentes}

A estrutura de valores concorrentes, seguindo a linha dos autores, utiliza quatro modelos opostos, simultaneamente, ao invés de valorizar apenas uma perspectiva e desvalorizar as opostas. Os direcionados da ação se baseiam em "Colaborar", "Controlar", "Competir" e "Criar" e por meio desses, os gerentes devem se envolver em uma variedade de tipos de comportamentos dependendo das circunstancias especificas. Essa estrutura segue a linha de pensamento de que “o mundo continua mudando", ou seja, as estratégias que são efetivas em uma situação hoje, amanhã já poderão não servir mais, ou até mesmo, enquanto para um tipo de situação elas são eficazes, para outras, precisam de mudanças. 
Seguindo essa mesma linha, os gerentes não podem ficar presos aos valores culturais da organização, empregando estratégias semelhantes em situações amplamente variadas.

Quinn et al. (2015 p. 18) afirmam que:

A estrutura de valores concorrentes completa, baseada nos quatro modelos descritos, pode aumentar a efetividade, ao ajudar os gerentes a expandir suas perspectivas. Cada modelo da estrutura indica valor em estratégias diferentes, até mesmo opostas. A estrutura reflete a complexidade enfrentada pelas pessoas em organizações reais. Por conseguinte, fornece uma ferramenta para ampliar o pensamento, aumentar as opções e a efetividade.

Diante disso, conclui-se que um bom líder gerencial é aquele que integra os valores opostos e se desenvolve a partir disso. É importante que o líder saiba aplicar diversos tipos de competências e ações diferentes, tal como demonstrado na figura 1.

A figura 1 apresenta a estrutura de valores concorrentes:

Figura 1 - Estrutura de Valores Concorrentes

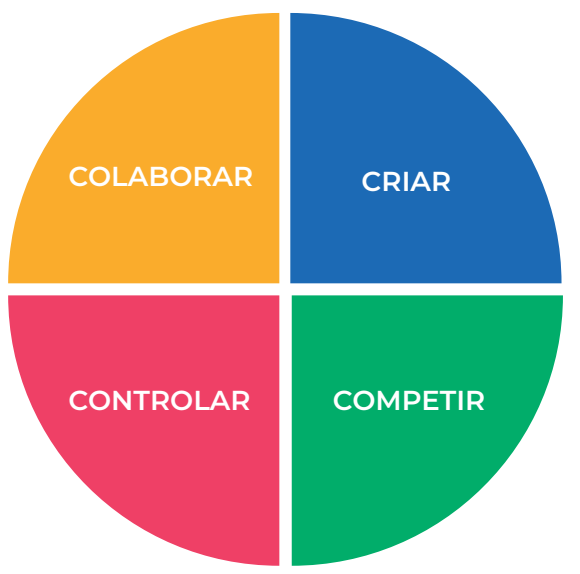

Fonte: Próprio autor (2019).

O primeiro tipo de ação, segundo o modelo, é associada ao quadrante colaborar, localizado na área superior esquerdo. Ele está associado ao modelo de relações humanas, responsável por criar e sustentar compromisso e coesão. É esperado que os gerentes estimulem uma comunicação aberta e respeitosa entre os 
membros, e para isso é necessário, primeiramente, entender o interesse dos outros e, principalmente, o seu próprio. É atribuição do gestor desenvolver as pessoas, gerenciar grupos e liderar equipes. Para isso é preciso estimular conflitos construtivos e desestimular os destrutivos, promovendo a confiança e o bem estar dos funcionários.

O segundo quadrante, localizado na parte inferior esquerda é associado ao controle. Tem como base manter estabilidade e continuidade, ou seja, os gerentes devem assegurar que estão cientes das questões internas da empresa, como por exemplo, se as pessoas estão seguindo as regras e a unidade está alcançando suas metas. Nesse caso, o desempenho deve ser medido tanto em relação à eficiência quanto à efetividade, e devem ser fornecidos feedbacks no memento oportuno.

O terceiro quadrante, localizado na parte inferior direita, representa o imperativo de ação competir. O foco é aumentar a produtividade e a lucratividade. Para isso, os gerentes devem ter amplo entendimento sobre o ambiente externo para estabelecer e desenvolver uma visão interna apropriada. Com o intuito de transformá-la em realidade, é preciso, além de comunicar aos funcionários sobre a visão, definir metas e esclarecer as expectativas sobre seus trabalhos. O gerente deve ser capaz de converter metas em ações. Devem incentivar a equipe e aumentar a produção para atingir metas definidas.

Já o quarto quadrante, localizado na parte superior direita, se relaciona ao modelo criar, ou seja, a capacidade de se adaptar à mudanças e adquirir suporte externo. O gerente deve prestar atenção no ambiente em transformação, identificar tendências importantes e estimular a inovação. Precisa também desenvolver modelos e acordos que transformem as suas ideias em ação.

Todos os quadrantes mencionados se associam ao líderes gerenciais em todos os níveis hierárquicos, por mais que cada um desenvolva estratégias diferentes para desenvolver o mesmo imperativo de ação. Por exemplo, um gerente de primeiro nível provavelmente vai realizar tarefas específicas e ter responsabilidades associadas do imperativo de ação "Criar" diferente dos demais gerentes da organização. Mas, independente disso, as competências requeridas para desenvolver esse imperativo muitas vezes são as mesmas, como, por exemplo ter boas habilidades interpessoais e alto nível de autoconhecimento 
O quadrante que será aprofundado nesse trabalho é o referente ao "Colaborar", que abrange quatro competências: Entender a si mesmo e os outros, Comunicar com honestidade e efetividade, Orientar e desenvolver pessoas e Gerenciar grupos e liderar equipes. As competências foco do estudo são a primeira e a segunda, ou seja, Entender a si mesmo e os outros e Comunicar com honestidade e efetividade.

Segundo Quinn et al. (2015), entender a si mesmo e os outros se relaciona a maneira como a pessoa reage à situações. É necessário desenvolver uma autoconscientização que permite um maior autocontrole. É importante também desenvolver a capacidade de entender os outros e trabalhar com eles com mais eficácia. Para isso, a inteligência emocional e social são elementos chave para aprimorar essa competência. A inteligência emocional, está relacionada à consciência do próprio caráter, traço de personalidade, reações emocionais, pontos fortes e fracos, valores e crenças centrais, e motivações, ou seja, com ênfase para o seu interior. E a inteligência social, com ênfase externa, incluindo a forma como a pessoa é percebida pelos outros. A medida em que essas inteligências são desenvolvidas, o líder adquire a capacidade de se gerenciar com eficácia e de interagir bem com os outros e em seus relacionamentos.

Os autores ressaltam também que os líderes, diferente dos outros profissionais, são responsáveis por reunir as diferentes funções das pessoas e criar um ambiente de trabalho coeso. Para isso é necessário que conheçam não apenas seus pontos fortes e fracos, mas também seu impacto no ambiente de trabalho. Sendo mais conscientizado sobre suas emoções e as dos outros, consegue reconhecer melhor habilidades específicas de cada um.

Os gerentes que entendem a si mesmo e os outros, compreendem também que os funcionários se diferenciam em sentimentos, necessidades e interesses, e que esses traços singulares fazem com o que eles reajam de formas diferentes à mesma relação. Esse fator deve ser visto como uma oportunidade para explorar formas diferentes se de se alcançar o sucesso. É importante que os líderes utilizem esse conhecimento para ajudar os funcionários a criar sua própria conscientização e seu potencial para o alcance de metas e objetivos da organização.

Uma outra competência essencial para ser desenvolvida, que necessita também do controle das emoções e a forma como ele impacta nas interações com 
o mundo exterior, é comunicar com honestidade e efetividade. Os gerentes passam maior parte de seu tempo, segundo Quinn et al. (2015), envolvidos em diversos tipos de comunicação (email, telefone, conversas, apresentações e etc) com o objetivo de informar, coordenar e motivar as pessoas. A comunicação pode ser associada com o desenvolvimento da inteligência social, ou seja, com a forma como se transmite para os outros o que se deseja.

A partir disso, o presente trabalho objetiva compreender a importância da inteligência emocional e social para o desenvolvimento dessas duas competências essenciais, sendo entender a si mesmo e os outros e comunicar com honestidade e efetividade, para um meio organizacional harmônico e competente. É importante que elas estejam presentes da vida dos gerentes, afinal, sua rotina de trabalho é marcada por constantes interações com as pessoas de diferentes personalidades. Na sequência, serão aprofundados os conceitos relativos à inteligência emocional e social.

\subsection{Inteligência emocional}

O conceito de inteligência emocional, segundo Goleman (2001, p. 337, apud Junqueira, Couto, Pereira, 2011, p. 2) é “(....) a capacidade que um indivíduo tem de identificar seus próprios sentimentos e os dos outros, de se motivar e de gerir bem as emoções internas nos relacionamentos”. É saber reconhecer e gerenciar as emoções de forma que elas impactam positivamente no cotidiano. O sucesso ou fracasso de alguém está diretamente ligado à inteligência emocional e a forma como ela é exposta a sociedade.

Segundo Goleman (2000, apud Quinn, 2015) a inteligência emocional tem como principais dimensões a conscientização e o autogerenciamento. O autogerenciamento está associado a capacidade do homem em regular as próprias emoções. Já conscientização se associa ao modo como o homem usa e aplica seus pontos fortes e capacidades. Ela inclui três áreas de foco. A primeira é a consciência emocional, relacionada a capácidade de reconhecer as emoções e a forma como elas afetam a si próprio e aos outros, entendendo as conexões entre seus sentimentos e ações. A segunda é a autoavaliação, que é a habilidade do homem em entender seus pontos fortes e limitações; para isso é importante que ele 
seja aberto a feedbacks, o que estimula a aprendizagem contínua e o autodesenvolvimento. Por fim, outra área de foco importante para a conscientização é a autoconfiança, associado ao senso sobre si mesmo, defendendo aquilo em que se acredita, mesmo quando sua opinião seja diferente dos demais.

O autor complementa que essas dimensões citadas podem ser melhoradas e desenvolvidas por qualquer indivíduo. Para que essas habilidades sejam postas em práticas o homem precisa refletir, se conhecer e criar novos hábitos e formas de pensar e se comportar.

Bradberry (2007) afirma que a inteligência emocional tende a aumentar conforme o homem amadurece e envelhece. O controle das emoções e dos comportamentos se tornam mais fácil na vida adulta. Os indivíduos com mais de 50 anos obtém uma pontuação $25 \%$ maior no teste de inteligência emocional se comparado ao resultado dos que possuem em torno dos 20. A tendência, segundo o autor, é a cada década se tornar mais inteligente emocionalmente.

Segundo Quinn et al. (2015) para que alguém tenham a capacidade de se autogerenciar, ou seja, regular as suas emoções, é preciso, primeiramente, que compreenda sua personalidade, pois assim terá uma melhor percepção sobre suas emoções, seus pontos fortes, fracos bem como a forma como as pessoas o percebem. Quando se entende o que motiva seu comportamento e reações, positivos ou negativos se adquire a capacidade de gerenciar suas ações e reações pelo mundo.

Pode-se dizer, então, que é relevante que cada pessoa compreenda seus atributos psicológicos e comportamentais relativamente permanentes, responsáveis por distinguir as pessoas entre si, ou seja, sua personalidade. Bradberyy (2007) complementa que personalidade é complexa e está intimamente ligada a inteligência emocional; percebendo sua personalidade, é possível controlar melhor suas emoções.

Segundo Bradberry (2007, p. 29):

Inteligência, personalidade e inteligência emocional, são qualidades distintas que todos nós possuímos. Juntas, determinam como pensamos e como agimos. É possível prever uma dessas qualidades baseando-se na outra. As pessoas podem ser brilhantes, mas não emocionalmente inteligentes, e os mais diversos tipos de 
personalidades podem ter a inteligência ou inteligência emocional elevada. Das três, a inteligência emocional é a única flexível e mutável.

Enquanto Bradberry (2007) atribui a forma como o homem interage com as outras pessoas como uma das competências associadas a inteligência emocional, Quinn et al. (2015), diferentemente, afirmam que a inteligência emocional é focada em atributos internos do homem e a inteligência social é associada a forma que ele interage com o meio externo. Bradberry (2007) compreende que a inteligência emocional tem como base duas competências: a pessoal e a social. A primeira voltada mais para o "eu interior", se referindo a autoconsciência e ao autocontrole, resultante da percepção das emoções e a segunda se refere a consciência social e a administração dos relacionamentos, ligadas a interatividade com as outras pessoas, que será mencionada posteriormente junta com a inteligência social.

Seguindo Bradberry (2007, p.74), a competência pessoal se relaciona a “(...) capacidade de conhecer a si mesmo e de aproveitar o máximo de seu potencial. Não significa ser perfeito ou ter controle total de suas emoções, mas permitir ser guiado pelos sentimentos." É saber identificar as emoções e as possíveis reações diante dos acontecimentos e ter o controle sobre seu modo de reagir a situações ou pessoas.

O autor complementa que o maior obstáculo para desenvolver essa competência é a tendência do homem em querer evitar o sofrimento causado pela autoconsciência, ou seja, ter uma enorme dificuldade em admitir suas fraquezas e encarar o sofrimento para superá-lo. Esse fator, segundo o autor, pode implicar em diversas perturbações emocionais. $\mathrm{O}$ autor ressalta também que essas angústias que provocam uma barreira, ao serem enfrentadas de frente, muitas vezes podem ser percebidas como um problema não tão grave.

Outra forma de enfrentar as angústias e aprimorar a competência pessoal, segundo o autor, é controlar seu comportamento, ou seja, controlar suas tendências ao longo da vida e usar essa habilidade em diversas situações. É necessário descobrir as situações que provocam fortes emoções e como agir diante delas. Técnicas que facilitam esse exercício são: descrever como se sente e o que pensa diante de situações perturbadoras, conversar consigo mesmo (ajudando a 
controlar seu próximo passo e emoção), conversar com pessoas próximas a fim de ouvir s sobre seu comportamento, criar uma estratégia para lidas com essas emoções, e pensar antes de reagir diante de uma situação em que sua emoção ganhe muita força. Assim será mais fácil identificar seus padrões e estabelecer a relação entre um acontecimento e a forma com você responde a ele.

Para promover mudanças positivas sobre a sua vida, os autores Quinn et al. (2015) acrescentam que é importante identificar mudanças desejáveis e sustentáveis que se quer implementar. Para isso, primeiramente devem ser feitas diversas perguntas reflexivas despertando o seu "eu ideal", explorando formas verdadeiras de mergulhar dentro de si mesmo, como: “quem eu quero ser?". A partir disso, é possível começar a identificação de seus pontos fortes e habilidades que precisam ser alcançados, possibilitando a criação de um plano de ação para promover mudanças.

Uma estrutura simples que pode ajudar a desenvolver uma imagem mais realista sobre si mesmo, utilizada pelo autor, é a chamada Janela Johari, desenvolvida por Joseph Luft e Harry Ingham (1996). Essa janela faz uma ponte entre a importância inteligência emocional e social para que o homem entenda mais sobre si mesmo e os outros. Ela é composta por quatro quadrantes, como ilustrado abaixo na figura 2 :

Figura 2 - Janela Johari.

\begin{tabular}{|c|c|c|}
\hline Outro & $\begin{array}{c}\text { Conhecido } \\
\text { pelo outro }\end{array}$ & $\begin{array}{c}\text { Desconhecido } \\
\text { pelo outro }\end{array}$ \\
\hline $\begin{array}{c}\text { Conhecido } \\
\text { pelo próprio }\end{array}$ & Área livre & Área secreta \\
\hline $\begin{array}{c}\text { Desconhecido } \\
\text { pelo próprio }\end{array}$ & Área cega & Área inconsciente \\
\hline
\end{tabular}

Fonte: Próprio autor (2019). 
Os autores Quinn et al. (2015) afirmam que a área aberta representa aspectos do que você realmente é que são conhecidos por você mesmo e pelos outros A área cega representa aspectos que os outros veem em você mas você mesmo não é capaz de enxergar. A área oculta apresenta aspectos que você conhece sobre si mesmo, mas não revela aos outros. A área desconhecida apresenta aspectos sobre quem você é que nem você sabe e nem os outros ao seu redor. Esses, quando são descobertos trazem juntos uma bagagem de autorreflexão, importantes para o crescimento pessoal.

Esses quadrantes são moldados de acordo com aspectos ligados a sua inteligência emocional e a forma como interage com o mundo. Ou seja, uma pessoa pode ter o primeiro quadrante maior do que os demais por ser mais extrovertida e desinibida, já uma pessoa mais tímida por apresentar o terceiro quadrante maior do que os demais.

Vale reforçar que, segundo os autores Quinn et al. (2015), os elementos do "eu" mudam com o tempo. Em relacionamentos novos, por exemplo, o quadrante "Aberto" é pequeno, mas a medida que a comunicação aumenta e a confiança ganha força ele cresce e o "Oculto" por exemplo começa a encolher, ou seja, o próximo começa a conhecer mais a fundo você.

Segundo a linha de pensamento dos mesmos autores, nas empresas, é aconselhável que o quadrante aberto seja de maior tamanho e, consequentemente, os demais de menor tamanho. Procurar pensar e aprender sobre si mesmo, faz com o que as pessoas que estejam ao redor sintam-se mais a vontade em trocar informações e, assim, mais recursos são direcionados para o crescimento e desenvolvimento pessoal, o que resulta em maior abertura, confiança e aprendizado.

Os autores complementam que é importante que os outros saibam que você é uma pessoa aberta, inclusive nas empresas. Um meio de mostrar ser uma pessoa aberta é compartilhar informações sobre si mesmo. Ben Datter (2008 apud Quinn et al. 2015, p. 51) observou que: "quanto mais eles você (o gerente) puder contar a seus funcionários a respeito do que você valoriza, o que o motiva e como você trabalha, maior é a probabilidade de poder criar um diálogo aberto sobre como trabalhamos juntos". 
A partir disso, o conceito de inteligência emocional pode ser interligado com o assunto que será abordado no próximo tema, relacionado a inteligência social. O autor concluiu que para desenvolver um bom relacionamento entre líderes e liderados , é preciso que, primeiramente, seja feita uma reflexão sobre a forma como o homem enxerga a si mesmo e como ele utiliza dessa habilidade ao seu favor, como foi explicado anteriormente.

\subsection{Inteligência social}

Inteligência social, segundo Quinn et al. (2015), é a forma como o homem é percebido pelos outros em um contexto social, gerenciando suas relações e desenvolvendo uma consciência social ampliada. Goleman (2006), se refere a inteligência social como a capacidade de compreender os indivíduos e se relacionar com eles, captando emoções alheias e até mesmo pensamentos e sentimentos, estabelecendo interações com sucesso.

Quinn et al. (2015), complementam que a inteligência social é composta por consciência social e a facilidade social.

A primeira significa a forma como a pessoa se sente em relação aos outros, ou seja, refere-se a capacidade de sentir os sentimentos e pensamentos alheios, compreendendo situações sociais complicadas. Nessa primeira categoria estão incluídos:

- Empatia primordial: Ocorre quando o homem sente com os outros, ou seja, sentem com os sinais emocionais não-verbais as emoções das outras pessoas. Há uma leitura espontânea sem precisar que as pessoas falem, são mensagens passadas dos olhos.

- Sintonia: ouvir com total receptividade. Configura-se em uma presença completa de uma pessoa em relação a outra, facilitando a conexão. Há uma atenção total e busca pela compreensão, saindo da zona da opinião própria.

- Precisão empática: entender os pensamentos, sentimentos e intenções dos outros. Baseia-se na empatia primordial mas, com um 
entendimento explicito do que o outro sente e pensa, ou seja, serem exatos na leitura um do outro.

- Cognição social: O conhecimento de como o mundo social realmente funciona. As pessoas com esse conhecimento sabem o que esperar na maior parte de qualquer situação social.

Já a segunda categoria, ainda segundo Quinn et al. (2015) referente a facilidade social, relaciona-se à forma de ação diante dessa consciência, ou seja, se baseia em usar a interpretação do outro, para permitir interações fluentes e eficazes. Essa categoria inclui:

- Sincronia: Interação fluente no nível não-verbal. Para entrar em sincronia é preciso que ambos leiam instantaneamente as dicas não verbais e ajam de acordo com isso. Como por exemplo, quando um balança a cabeça ou sorri e o outro automaticamente o copia.

- Apresentação pessoal: Apresentar-se de maneira eficiente, ou seja, a capacidade de se apresentar causando a impressão desejada. Saber utilizar a expressão das emoções no momento e na forma correta pode ser considerado o segredo da apresentação pessoal.

- Influência: Moldar o resultado das interações pessoais, ou seja, quando o homem se expressa a fim de produzir um resultado social desejado. Para moldar uma situação é preciso de autocontrole e tato.

- Preocupação: Se importar com as necessidades dos outros e agir com base nelas. A preocupação se associa à empatia, juntas, o impulso em ajudar o próximo se torna mais forte e poderoso. São pessoas suscetíveis ao contagio emocional e assumem responsabilidades em prol de algo ou alguém. Ela reflete a capacidade de compaixão da pessoa.

Esses dois conceitos de consciência social e facilidade social estão diretamente interligado com a competência de se comunicar com honestidade e efetividade. Segundo Quinn et al. (2015) a comunicação interpessoal pode ser considerada uma das competências mais importantes que um gerente deve ter, pois eles estão constantemente envolvidos em vários tipos de comunicação. É 
importante saber trocar informações, fatos, ideias e significados, informando, coordenando e motivando as pessoas. Para isso, é importante ser um bom comunicador quando se é um líder. Os problemas resultantes da falta de uma boa comunicação podem afetar o desempenho da empresa.

Bradberry (2007) complementa que um passo primordial para construir uma consciência social é saber ouvir o próximo. Para realmente ouvir e absorver algo com convicção é preciso, primeiramente, interromper muitas coisas que dão prazer e servem como distração, ou seja, é necessário eliminar barreiras inibidoras da conversa, como por exemplo, celular, papeladas, barulhos, e até mesmo o diálogo interno.

O autor afirma que o conhecimento do meio externo é obtido por meio dos cinco sentidos: paladar, tato, olfato, visão e audição. A visão e a audição são os principais para dar a capacidade de avaliação dos fatos. Já o sexto sentido é o canal de percepção das emoções, e uma forma importante de obter informações nas interações com as pessoas.

Para ouvir o próximo é necessário deixar a pessoa a vontade para falar e interpretá-la sem permitir que seus próprios pensamentos interfiram em seu julgamento, ou seja, deixar a pessoa falar sem se sentir desconfortável. Quando o ser humano foca o pensamento mais nos outros e no que os outros estão querendo transmitir do que em si mesmo, além dos outros reagirem melhor, ele obterá uma capacidade maior de perceber as pessoas.

Quinn et al. (2015) complementam a importância da escuta reflexiva, ou seja, escutar utilizando a ferramenta da empatia, ajudando a vivenciar os pensamentos e sentimentos da outra pessoa, e consequentemente facilitando a forma como ela se expressa. Esse tipo de escuta traz maior confiança e interesse, além de soluções de problemas mais efetivas e duradouras.

Ainda segundo os autores, mesmo se a condição de ser bom ouvinte e saber se expressar bem estiverem presentes, podem ocorrer problemas em decorrência de condições do ambiente físico (frio, barulhento e etc.) ou outros elementos de distração. Quanto maior for a complexidade e a emoção envolvida na mensagem, maior deve ser a preocupação do gerente em usar opções de 
comunicação ricas e uma seleção mais ampla de meios de comunicação. Como por exemplo, comunicação verbal em conjunto com elementos por escritos.

Nas comunicações podem ocorrer também o fato das pessoas estarem "pensando mas não dizendo" ou "pensando o que os outros estão pensando mas não dizendo", ou seja, problemas "deixados de fora" da conversa. Em vez das pessoas trazerem o problema à tona, elas contornam, evitam, inventam ou dizem coisas que não queria ou acreditam. Como resultado disso, a confiança entre as pessoas diminuem e consequentemente seu desempenho na empresa.

É importante que as pessoas saibam trazer à tona os problemas de forma positiva, ao invés de ocultá-los, desenvolvendo habilidades agregadores ao expressar preocupações. Para isso, o autor afirma que os gerentes precisam estar abertos e serem honestos com seus funcionários. Além disso, para se expressar bem é preciso saber antes quem é o receptor e seu estado de espirito, qual o objetivo da mensagem, o que será necessário para ajudar o receptor a estar aberto a comunicação, revisar a mensagem em mente antes de dizê-la, comunicar com palavras e termos familiares com o receptor, ser claro, e caso a resposta apareça negativa, tentar entender o que o receptor está pensando e por que ele está reagindo dessa maneira.

Por fim, o autor Boyatis (2006), relaciona a inteligência social com o papel da liderança nas empresa e afirma que para ser um grande líder é preciso inspirar seus liderados e criar relacionamentos ressonantes, mas, para isso, é necessário antes que ele que trabalhe para ser uma pessoa melhor e se sinta inspirado para isso. Além disso, o autor destaca perguntas chaves que os líderes devem ter em mente:

- Sou uma pessoa que cria inspiração?

- Crio um tom geral emocionante positivo que é caracterizado pela esperança?

- Estou em contato com outras pessoas? Sei o que se passa em seus comrações e suas mentes? Experimento e demonstro compaixão?

- Tenho verdadeira consideração e sintonia comigo, com os demais e com o ambiente? 
A partir da ideia do autor, pode-se concluir que antes de qualquer ação é preciso que haja uma reflexão sobre o impacto que poderá causar ao mundo. A forma como o líder pensa e age dentro das empresas gera um impacto positivo ou negativo nas pessoas que estão ao seu redor. 


\section{Métodos e procedimentos de coleta e de análise de dados do estudo}

Esse capítulo detalha a maneira como os dados necessários para a pesquisa foram coletados e a forma como foram utilizados.

\subsection{Método de Pesquisa Utilizado}

Segundo Vergara (2004) qualquer estudo deve informar o tipo de pesquisa realizada. A autora define dois critérios básicos para descrever os diversos tipos de pesquisas existentes: quantos aos fins e quanto aos meios. O primeiro refere-se a uma pesquisa que pode ser classificada como exploratória, descritiva, explicativa, metodológica, aplicada ou intervencionista. Já quanto aos meios, a pesquisa pode ser de campo, de caso, de laboratório, documental, bibliográfica, experimental, ex-post facto, participante ou pesquisa-ação.

A pesquisa realizada no presente estudo, quanto aos fins, é descritiva, que segundo Vergara (2004), tem por objetivo descrever as características de um determinado fenômeno, que no caso abordado, é a inteligência emocional e social dos líderes pela visão dos seus liderados. Já em relação aos meios, o estudo foi de caso, de campo, bibliográfico, documental e participante. A pesquisa de campo foi necessária porque houve a investigação no local, utilizando um questionário para compreender a percepção dos liderados sobre seus líderes, em relação a sua inteligência emocional e social, e como isso impacta no seu trabalho. Foi um estudo de caso por utilizar uma empresa específica e bibliográfica pois foram utilizados livros e pesquisas sobre o tema em questão. Além disso, ela foi documental porque documentos internos da organização - como organograma, níveis hierárquicos - também foram fonte de consulta e participante, pois o pesquisador tem contato e interage com os pesquisados e a empresa. 


\subsection{Estrutura do Questionário e Coleta de dados}

Para a elaboração do questionário, foram formuladas 29 perguntas. Participaram da pesquisa liderados que atuam no Rio de Janeiro, dos setores financeiro, vendas, contabilidade fiscal, controladoria, estamparia, manutenção, montagem, Planejamento e Controle da Produção (PCP), suprimentos, entre outros, tal como detalhado na Tabela 1. O objetivo do questionário foi compreender como os pesquisados percebem a atuação de seus líderes com foco nas inteligências emocional e social, e como isso os afeta. $\mathrm{O}$ questionário foi aplicado via disponibilização por email de um link para todos os participantes. Inicialmente foi feito um teste com o instrumento de pesquisa e, após ser analisado e adaptado, foi enviado para os participantes da pesquisa. $\mathrm{O}$ instrumento de pesquisa utilizado segue no Apêndice 1.

No total,57 profissionais receberam o link da pesquisa e 40 responderam o instrumento de coleta de dados. $\mathrm{o}$.

Tabela 1 - Setores x quantidade de respondentes.

\begin{tabular}{|c|c|}
\hline SETORES & Quantidade de respondentes \\
\hline ADMIN.ECONOMICOIFINANCEIRO-RJ & 2 \\
\hline ADMINISTRACAO VENDAS-RJ & 5 \\
\hline CONTABILFISCAL-RJ & 6 \\
\hline CONTROLADORIA-RJ & 4 \\
\hline CONTROLE DE QUALIDADE-RJ & 2 \\
\hline ESTAMPARIA-MOI-RJ & 2 \\
\hline EXPEDICAO-RJ & 3 \\
\hline FATURAMENTO-RJ & 2 \\
\hline GERENCIAINDUSTRIAL-RJ & 2 \\
\hline JURIDICO-RJ & 2 \\
\hline MANUTENCAO-RJ & 4 \\
\hline MONTAGEM-MOI-RJ & 2 \\
\hline PCP-RJ & 3 \\
\hline RECEPCAOMTELEFONIA-RJ & 2 \\
\hline RECURSOS HUMANOS-RJ & 4 \\
\hline SEGURANÇA DO TRABALHO-RJ & 2 \\
\hline SUPRIMENTOS-RJ & 7 \\
\hline TECNOLOGIA DA INFORMATICA-TI & 4 \\
\hline
\end{tabular}

Fonte: Próprio autor (2019). 


\subsection{Limitações do estudo}

Assim como todos os estudos, esse também possui algumas limitações. Primeiramente, não abrangeu todos os setores da empresa. A segunda limitação é que não houve a análise dos questionários por setor. A opção por apresentar essas respostas mais amplas foi para não impactar negativamente nenhum líder, visto que a autora do estudo possui relação familiar com o proprietário.

Além disso, o questionário limita as respostas (obtendo no máximo seis opções), assim, pode ser que os liderados não concordem 100\% com uma resposta, escolhendo àquela mais próxima de seu pensamento. Outro fator que pode ter limitado o estudo é que pode ter havido eventual dificuldade na compreensão das perguntas, pela ausência do pesquisador. Mesmo com as limitações indicadas, o estudo foi válido para coletar percepções sobre a influência da inteligência emocional e social na relação entre líderes e liderados.

Outro ponto que limita o estudo está relacionado ao fato da autora do trabalho possuir relação familiar com dono da empresa estudada. Logo, deve-se considerar a possibilidade de alguns participantes não responderem o questionário com total honestidade, visto que o assunto envolve seus líderes, com os quais a autora possui um contato maior. 


\section{Apresentação dos resultados}

Nesta seção são apresentados os dados obtidos a partir do questionário e as análises realizadas a partir do referencial teórico. Será dividida em quatro seções: informações gerais sobre a empresa; perfil dos respondentes; descrição e análise dos resultados e, por fim, a conclusão.

\subsection{A empresa}

A empresa estudada é a Litografia Valenca, atuante no mercado desde 1998 no setor de embalagens metálicas. A empresa possui unidades no Rio de Janeiro, São Paulo, Barra Mansa e Volta Redonda, sendo todas responsáveis por produzir e distribuir latas para outras empresas principalmente de tintas, petróleo e alimentos. São mais de 400.000 latas produzidas por dia com a ajuda de mais de 800 funcionários que fazem parte da equipe. A empresa é nacionalmente reconhecida, estando entre as três maiores do Brasil. Possui grandes clientes como Petrobras, AksoNobel, Ipiranga, Sherwin Willians, entre outros, e grande reconhecimento nacional e internacional no setor de embalagens metálicas, com diversos prêmios e certificações, segundo o site da empresa.

\subsection{Perfil dos pesquisados}

Dos 800 membros da empresa, a pesquisa focou apenas o escritório do Rio de Janeiro. Dos 57 funcionários que receberam o link da pesquisa, 40 responderam.

Dos 40 respondentes, $45 \%$ são mulheres e $55 \%$ são homens. A maior parte, $27.5 \%$, encontra-se na faixa entre 35 e 45 anos: 
Gráfico 1: Faixa etária dos entrevistados

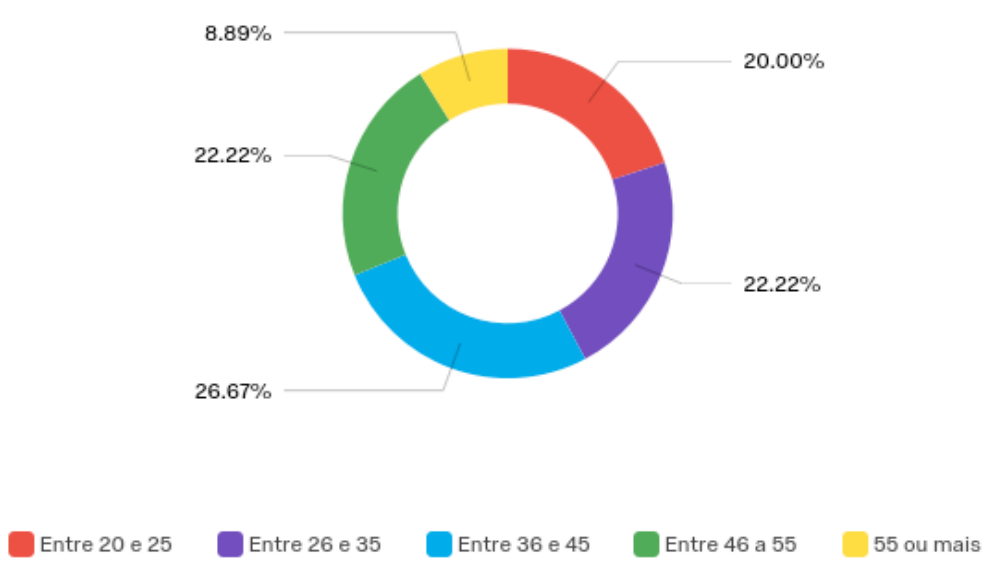

Fonte: Próprio autor (2019).

Já em relação ao tempo de empresa $12,5 \%$ estão há menos de um ano , $25 \%$ estão entre 1 e 5 anos, $27,5 \%$ estão entre 5 e 10 anos e $12,5 \%$ entre 10 e 15 anos e $22,5 \%$ possuem 15 anos ou mais de experiência na organização.

\subsection{Descrição e análise dos resultados}

As perguntas realizadas objetivaram identificar o quanto os liderados identificavam aspectos da inteligência emocional e social em seus líderes e se esses aspectos influenciavam ou não o seu resultado.

Primeiramente foram questionados sobre a preocupação do líder com a motivação da equipe e a criação de um ambiente de trabalho saudável, como apresentado no gráfico 2 . 
Gráfíco 2: O seu líder é preocupado em manter a equipe motivada e um ambiente de trabalho saudável?

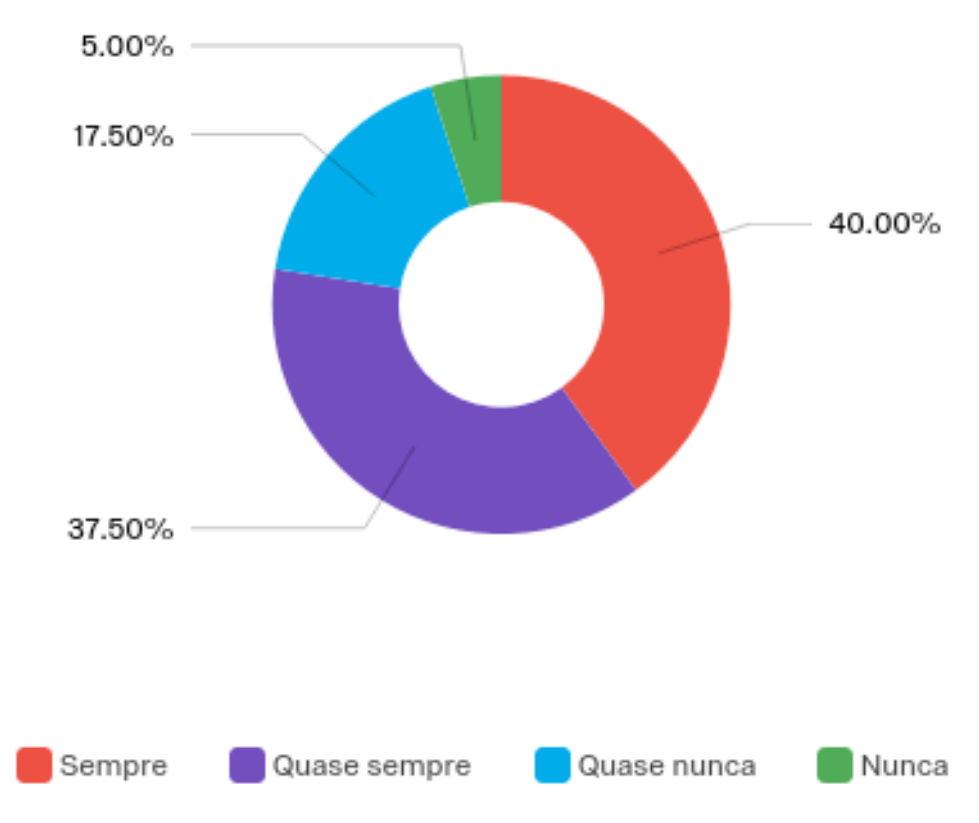

Fonte: Próprio autor (2019).

O gráfico 2 ilustra que 70,50\% dos respondentes acreditam que seu líder se preocupa em manter a equipe motivada e um ambiente de trabalho saudável, o que se relaciona com a inteligência social. Bittel (1982) afirma que o líder tem um papel fundamental na criação de um ambiente harmônico e Hunter (2004), que a liderança é a habilidade de influenciar seus liderados a trabalharem entusiasticamente, com sinergia e coesão. Diante disso, pode-se inferir que os líderes atuam em conformidade com esses dois itens.

Também relacionado à inteligência social, foi avaliado se a comunicação dos líderes é transparente, articulada e motivadora. 75\% dos pesquisados responderam que estão de acordo com a afirmação. Pode-se avaliar o resultado dessa resposta, segundo Quinn et al. (2015) que afirmam que a comunicação pode ser considerada a base para a criação de um ambiente organizacional desejado e é preciso que os líderes se preocupem em exercer essa competência de forma positiva. É importante saber trocar informações, fatos, ideias e significados, informando, coordenando e motivando as pessoas. 
Na sequência foi analisado se os líderes são considerados autoritários e possuem dificuldade para ouvir opiniões diferentes de forma receptiva, fator ligado a inteligência emocional e social. Como resultado, 65,12\% afirmaram que "nunca" ou "quase nunca". Mesmo a maioria afirmando que os líderes não são autoritários, há uma porcentagem considerável que discorda. Segundo Quinn et al. (2015), é esperado que os gerentes estimulem uma comunicação aberta com os seus funcionários, entendendo os diferentes interesses, promovendo confiança, desenvolvendo as pessoas, e se preocupando com o bem estar dos funcionários.

Quando questionados quanto a preocupação dos líderes em conhecer as dificuldades e limitações de cada liderado e buscar desenvolvê-las 72,5\% responderam que isso ocorre sempre ou quase sempre. O resultado indica que os líderes parecem atender ao especificado por Junqueira, Couto e Pereira (2011), que relatam que um papel importante do líder nas organizações é entender as necessidades de cada liderado e buscar equilibrá-las com a unidade de trabalho, qualidade desenvolvida a partir da inteligência social.

Já em relação aos feedbacks, Quinn et al. (2015) afirmam que problemas resultantes da falta de uma boa comunicação pode afetar odesempenho de seus integrantes. Para haver uma boa comunicação é preciso que os líderes saibam trocar informações e ideias, coordenando as pessoas. Ainda considerando o assunto feedback, foi questionada a forma como os liderados avaliam os feedbacks de seus líderes. Os resultados seguem nos gráficos 3, 4 e 5 . 
Gráfíco 3: O seu líder dá feedbacks construtivos?

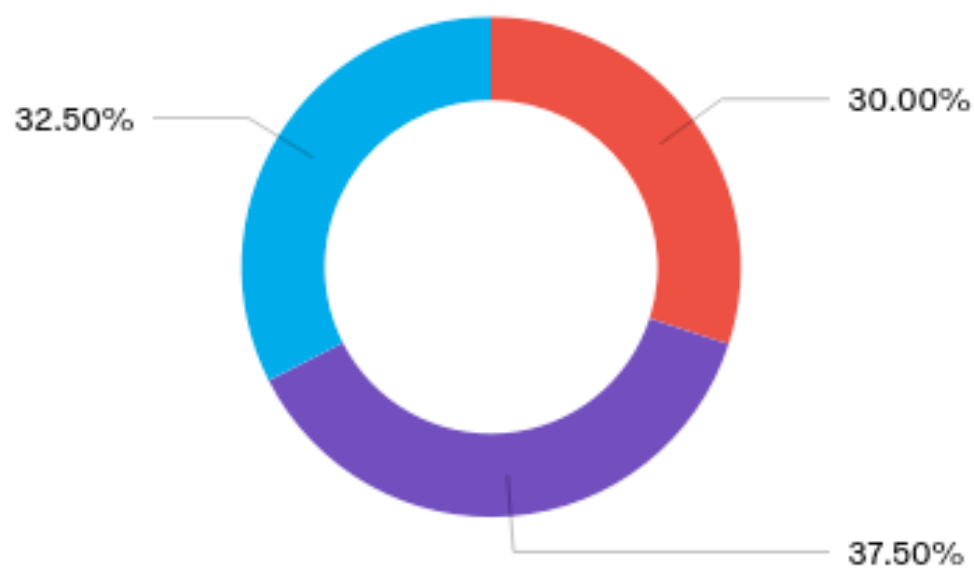

$37.50 \%$

Sempre

Quase sempre

Quase nunca

Nunca

Fonte: Próprio autor (2019).

Gráfíco 4: De 0 a 5 com que frequência você recebe feedbacks, pelo menos, mensalmente?

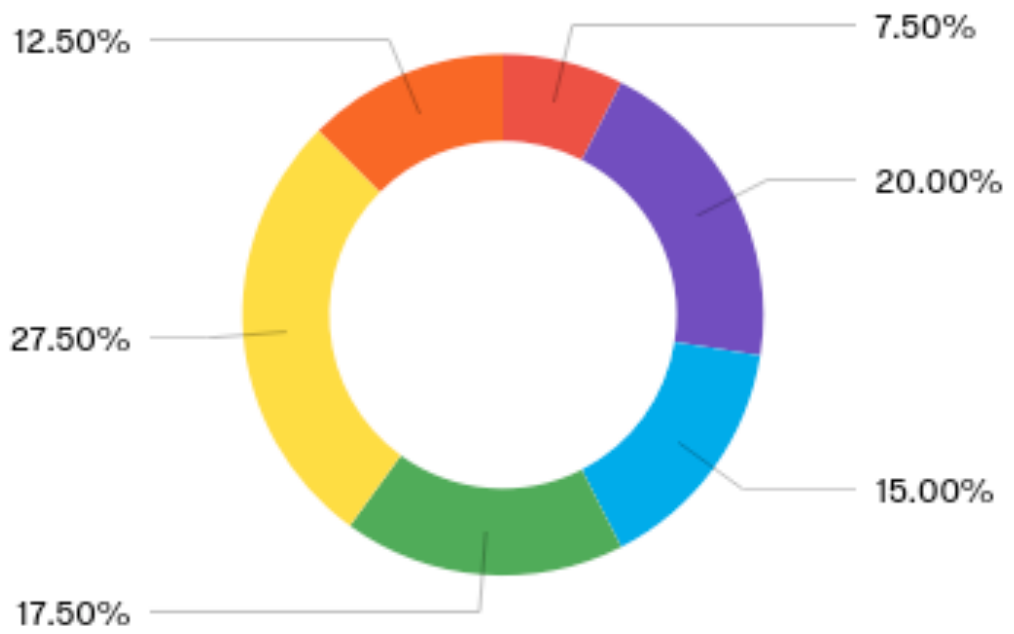

$\begin{array}{llllllll}0 & 1 & 2 & 3 & 4 & 5\end{array}$

Fonte: Próprio autor (2019). 
Gráfíco 5: De 0 a 5, qual é o nível de satisfação com os feedbacks.
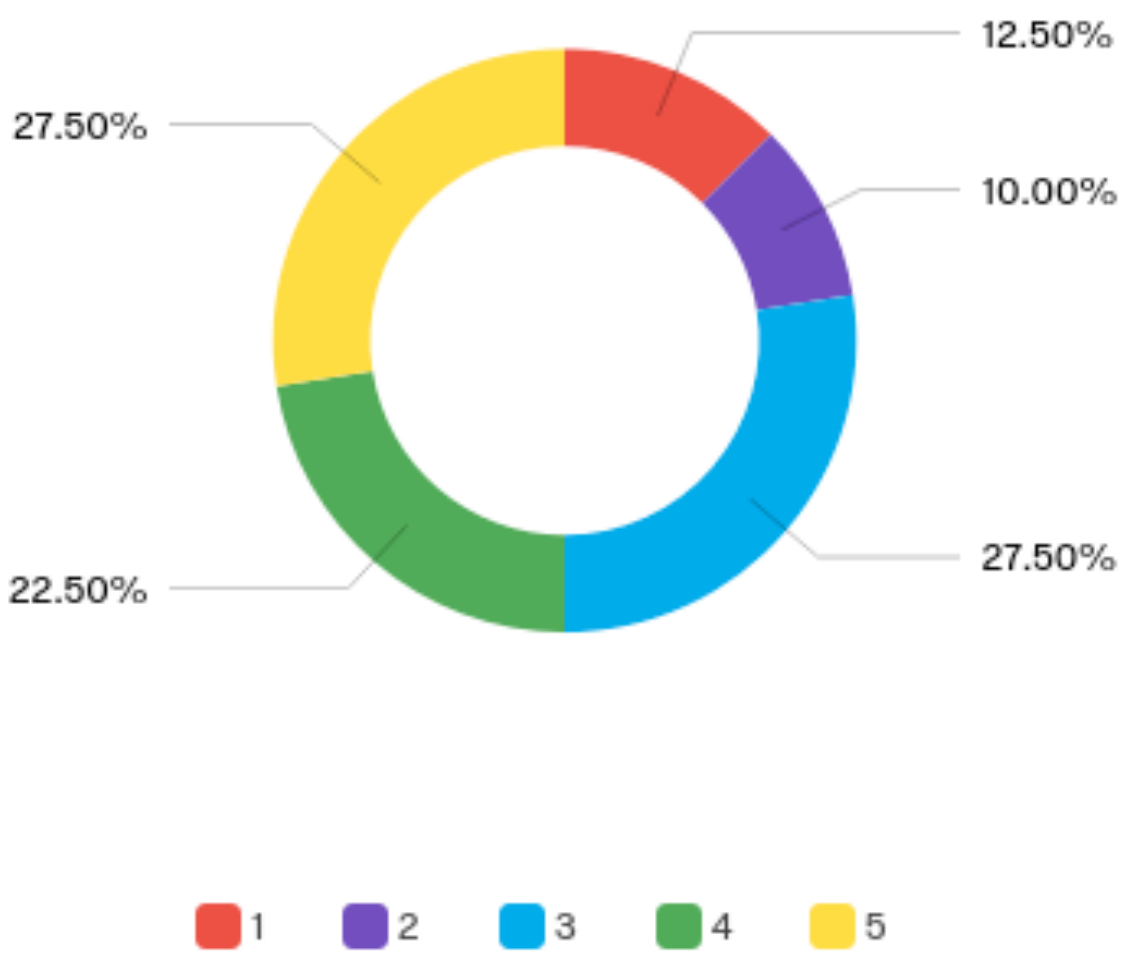

Fonte: Próprio autor (2019).

Os gráficos indicam se os feedbacks são construtivos ou não, qual é o seu nível de frequência e o nível de satisfação dos liderados com eles. As respostas indicam que os feedbacks fornecidos pelos líderes são vistos de forma positiva pelos seus liderados e que os mesmos são fornecidos com frequência. Foi também solicitado que os pesquisados justificassem o motivo do nível de satisfação com os feedbacks. Como resultado, 60\% afirmaram que os feedbacks costumam motivar, $10 \%$ que nem sempre entendem o motivo do feedback, $10 \%$ responderam que os feedbacks são indiferentes, e por fim $20 \%$ responderam que nenhuma das alternativas correspondia com o seu ponto de vista, sem obtenção de informação sobre seu próprio ponto de vista.

Foi analisado também se os liderados se sentem confortáveis em dar feedbacks ao seus líderes, dizendo o que incomoda ou agrada e a forma como eles podem melhorar. Como resultado 59,52\% acreditam que sempre ou quase sempre podem agir dessa forma. O resultado segue no gráfico 6: 
Gráfico 6: Você se sente confortável em dar feedbacks ao seus líderes, dizendo o que te incomoda ou agrada e a forma como ele pode melhorar?

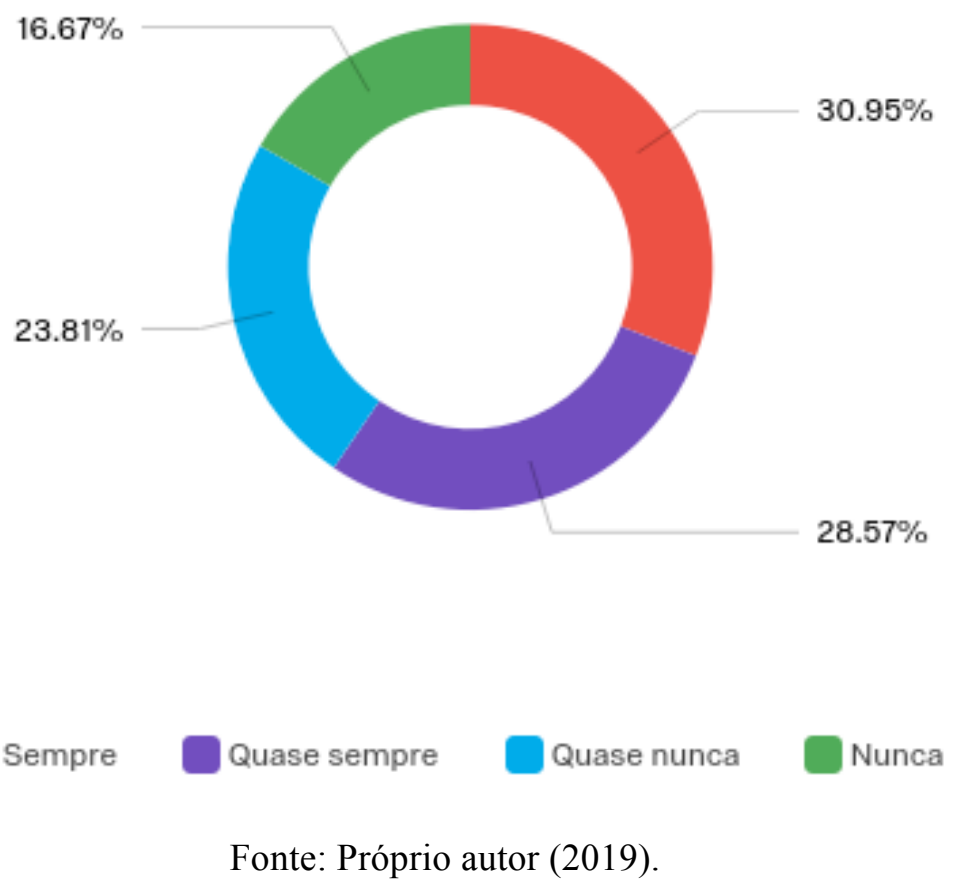

Quinn et al. (2015), afirmam que um indicador de inteligência social é estimular uma relação de abertura com os seus liderados, transmitindo confiança e vontade de aprender. É preciso que os liderados se sintam a vontade em trocar informações e dar feedbacks para os líderes, e para isso é preciso que os líderes sejam abertos e estimulem essa troca. $\mathrm{O}$ resultado do questionário indica que a maioria percebe esse aspecto da inteligência social em seus líderes.

Em seguida, foi questionado se o líder costumava descontar seus problemas pessoais no ambiente de trabalho. 95\% das respostas afirmaram que não. Os 5\% que afirmaram que sim foram direcionados a outra pergunta que avaliava se esses problemas pessoais afetavam seu resultado. Como resposta, $100 \%$ afirmaram que sim, que os problemas pessoais dos líderes atrapalham o rendimento dos liderados. Segundo Bradberry (2007) é importante saber identificar as emoções e as possíveis reações diante dos acontecimentos, e assim ter controle sobre seu modo de reagir a situações ou pessoas, sendo um indicador de inteligência emocional. Após análise do resultado desse questionamento percebe-se que os líderes da organização, na maioria das vezes, costumam 
controlar suas emoções para que ela não afete os outros, o que é um indicador de inteligência emocional.

Outra pergunta buscou identificar se o líder conhece seus próprios pontos fracos e procuram melhorá-los. As respostas seguem no gráfico 7:

Gráfico 7: O seu líder conhece seus próprios pontos fracos e procuram melhorá-los?

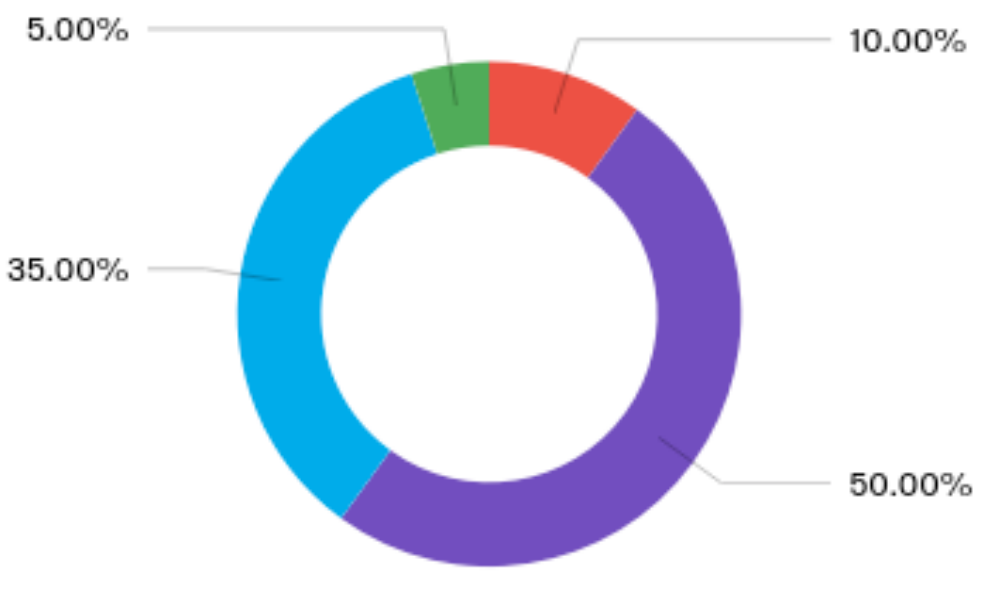

Sempre

Quase sempre

Quase nunca

Nunca

Fonte: Próprio autor (2019).

Segundo Goleman (2000, apud QUINN, 2015), conhecer seus próprios pontos fracos e procurar melhorá-los está ligado a autoavaliação, conceito atrelado a inteligência emocional. $\mathrm{O}$ autor afirma que é necessário reconhecer e entender seus pontos fortes e suas limitações e a partir delas, estimular a aprendizagem contínua e o autodesenvolvimento. Ao observar o gráfico 6 é possível perceber que $60 \%$ dos pesquisados acreditam que seus líderes conhecem e tentam mudar seus pontos fracos.

Outro ponto abordado foi se os liderados acreditam que os líderes deixam que as suas próprias emoções afetem negativamente assuntos ligados à empresa. Apenas 5\% acreditam que as emoções dos líderes afetem negativamente assuntos 
ligados a empresa, e 95\% acreditam que não interferem. Esse fator também pode ser associado à inteligência emocional, pois segundo Goleman (2000, apud Quinn, 2015), é necessário haver a consciência emocional, ou seja, a capacidade de reconhecer as suas emoções e a forma como elas afetam a si mesmo e aos outros.

Também em relação a forma como os líderes agem, na pergunta seguinte foi questionado como o liderado acha que os líderes lidam com os problemas do dia a dia. As respostas seguem no gráfico 8.

Gráfico 8: Como você acha que os líderes lidam com os problemas do dia a dia?

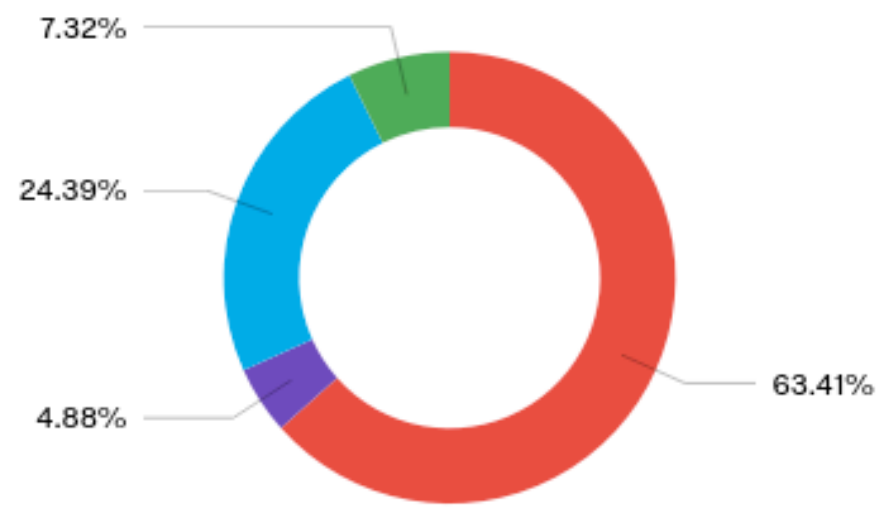

Costumam encarar o desafio de frente

Costumam depositar em outras pessoas

Costumam perder tempo se estressando pela causa do problema

Costumam postergar a soluçāo do problema

Fonte: Próprio autor (2019).

Por mais que $63,41 \%$ acreditem que eles costumam encarar o desafio de frente, $36,59 \%$ acreditam que os líderes costumam perder tempo se estressando, ou depositam o problema em outras pessoas, ou até mesmo postergam a busca pela solução. Segundo Bradberry (2007) enfrentar problemas e superar as angústias é considerado uma das maiores dificuldades para aqueles que querem desenvolver a competência pessoal. Pode-se analisar, então, que a maioria dos participantes acreditam que seus líderes são capazes de encarar a dificuldade de 
frente e impedir que as suas angústias criem barreiras que os prejudiquem, indicando o uso da inteligência emocional.

Outro ponto pesquisado foi se os líderes da empresa sabem como se comportar diante de alguma situação com a qual não esteja acostumado. A maioria, $88 \%$, acredita que sim, que possuem o autocontrole para se moldar em determinada situação. Segundo Quinn et al. (2015), esse fator possui relação com a inteligência social, pois é importante que o líder gerencial saiba se apresentar causando a impressão desejada, independente da situação.

Quando foram questionados se o líder é uma pessoa fechada, ou seja, que procura não criar uma intimidade maior com os liderados, $66,66 \%$ dos participantes discordaram total ou parcialmente. Ser uma pessoa fechada está de acordo com a área oculta da Janela Johari, que, segundo Quinn et al. (2015), é a área que apresenta aspectos sobre você que não são compartilhados para os outros. Ainda segundo os autores, é aconselhável que os líderes da organização sejam mais abertos, deixando que os outros o conheçam, visto que isso facilita o estabelecimento de uma relação com maior confiança. Esse conceito pode ser associado tanto à inteligência social quando emocional, pois é preciso se permitir ser aberto para interagir bem com os outros.

Já quando foi feito um questionamento se os liderados consideram o líder uma pessoa empática, ou seja, capaz de sentir e entender as emoções dos membros da equipe e procurar ajudá-los as respostas foram as que seguem no gráfico 9: 
Gráfico 9: Seu líder é uma pessoa com empatia, ou seja, capaz de sentir e entender as emoções dos membros da equipe e procura ajudá-los?

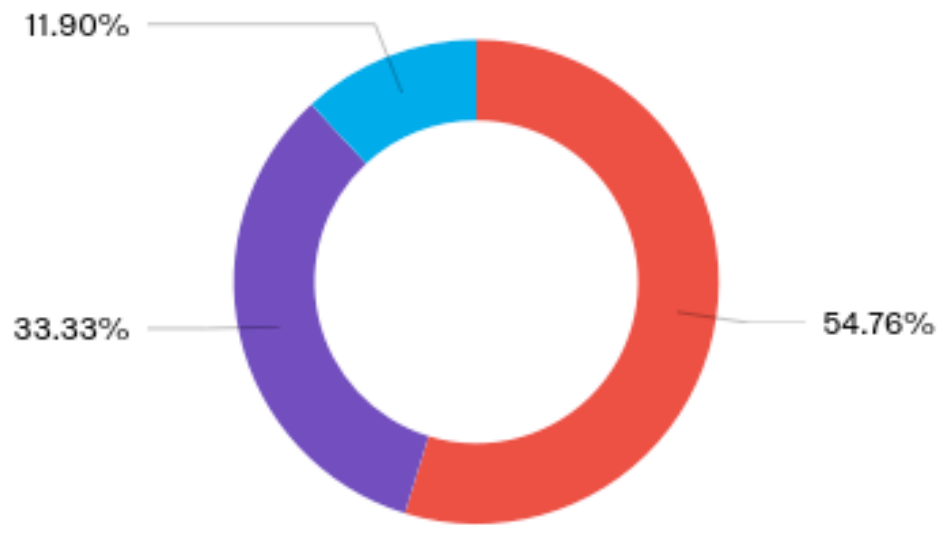

Sim, ele é capaz de sentir, entender e ajudar

Sim, ele é capaz de sentir, mas nem sempre entender ou ajudar

Nāo, ele nāo costuma sentir, entender e ajudar

Fonte: Próprio autor (2019).

Segundo o gráfico $9,54,76 \%$ acreditam que os líderes são empáticos, ou seja, sentem, entendem e ajudam os liderados, 33,33\% acreditam que são parcialmente, pois nem sempre entendem ou ajudam e 11,90\% acreditam que eles não são. Dentre aqueles que votaram que os líderes são empáticos ou parcialmente empáticos, $82,61 \%$ acreditam que a empatia dos líderes melhora os rendimentos dos liderados da empresa, 17,39\% acreditam ser indiferente. Já em relação aos pesquisados que responderam que os líderes não são empáticos, $80 \%$ indicaram acreditar que a falta de empatia afeta o rendimento deles na empresa. Esse resultado pode ser associado o conceito de consciência social, segundo Quinn et al. (2015). Os autores defendem é necessário possuir empatia para ser inteligente socialmente, sendo capaz de sentir e entender os sentimentos e emoções dos outros. Assim sendo, a maior parte das respostas indica que os líderes possuem esse aspecto da inteligência emocional. 
Os líderes também foram avaliados em relação a importância que conferem às necessidades dos subordinados. Como resultado, 73,81\% acreditam que os líderes quase sempre ou sempre se importam com suas necessidades. Quinn et al. (2015) associam esse ponto a prática da inteligência social. Os autores afirmam que é essencial se importar e agir com base nas necessidades dos liderados para se tornar um líder gerencial. Foi avaliado em uma próxima questão se esse fator é importante para a criação de uma boa relação no ambiente de trabalho, e, assim como no resultado acima, a 73,5\% acreditam ser importante, o que associa as práticas da inteligência social para manter o ambiente agradável.

As próximas quatro questões serão analisadas em conjunto pois estão associadas da mesma forma à teoria. Sendo elas: a capacidade do líder para gerir as pessoas. O resultado é ilustrado no gráfico 10 :

Gráfico 10: Qual é a capacidade do seu líder para gerir as pessoas?

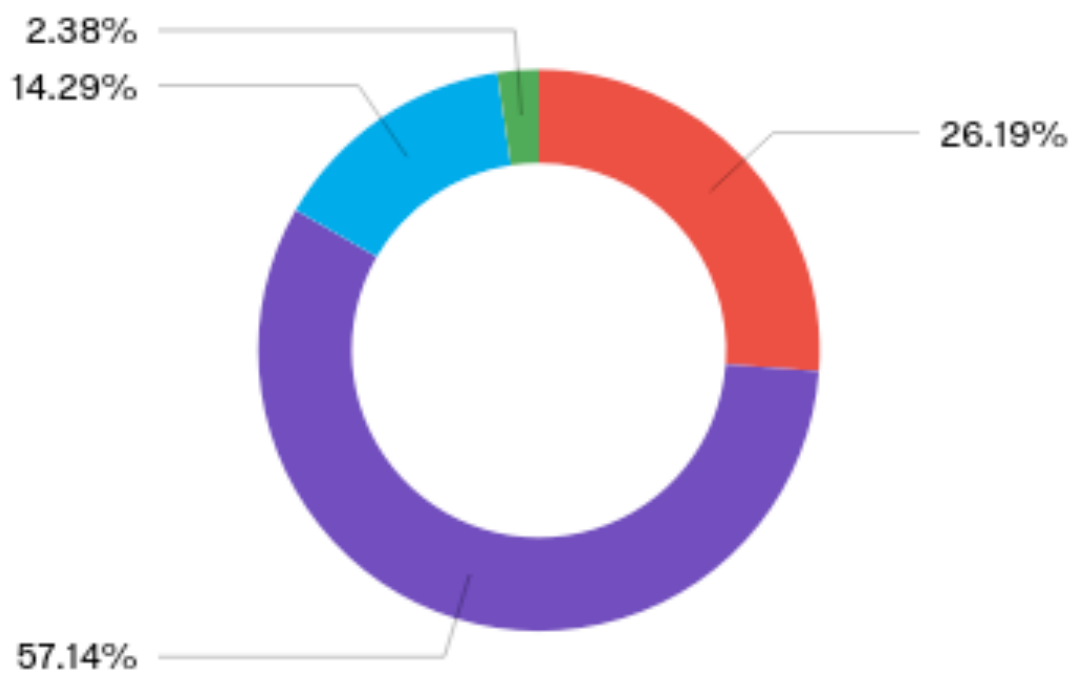

Muito boa Boa Ruim Muito ruim

Fonte: Próprio autor (2019).

Com base no gráfico 10 percebe-se que a maioria dos liderados acredita que seus líderes são capazes de gerir seus liderados de forma positiva, totalizando 
$83,33 \%$. A outra questão avaliava a relação do liderado pesquisado com o seu líder, e 90,48\% informaram que a relação é positiva.

A próxima pergunta questionava, de forma direta, se a relação que o líder tem com os liderados afeta o rendimento deles na empresa. Como resultado $65 \%$ acreditam totalmente ou parcialmente que o seu rendimento na empresa está atrelado a sua relação com seu líder. E, por fim, foi analisado o quanto o liderado acredita que a forma como o líder interage com ele interfere no seu dia a dia e no seu desenvolvimento profissional. Como resposta, obteve-se o gráfico 11, ilustrando que $73,5 \%$ acreditam que a forma como o líder interage impacta a rotina de trabalho dos seus liderados de certa forma.

Gráfico 11: De 0 a 5, quanto você acredita que a forma como o líder interage com você interfere no seu dia a dia e desenvolvimento profissional?
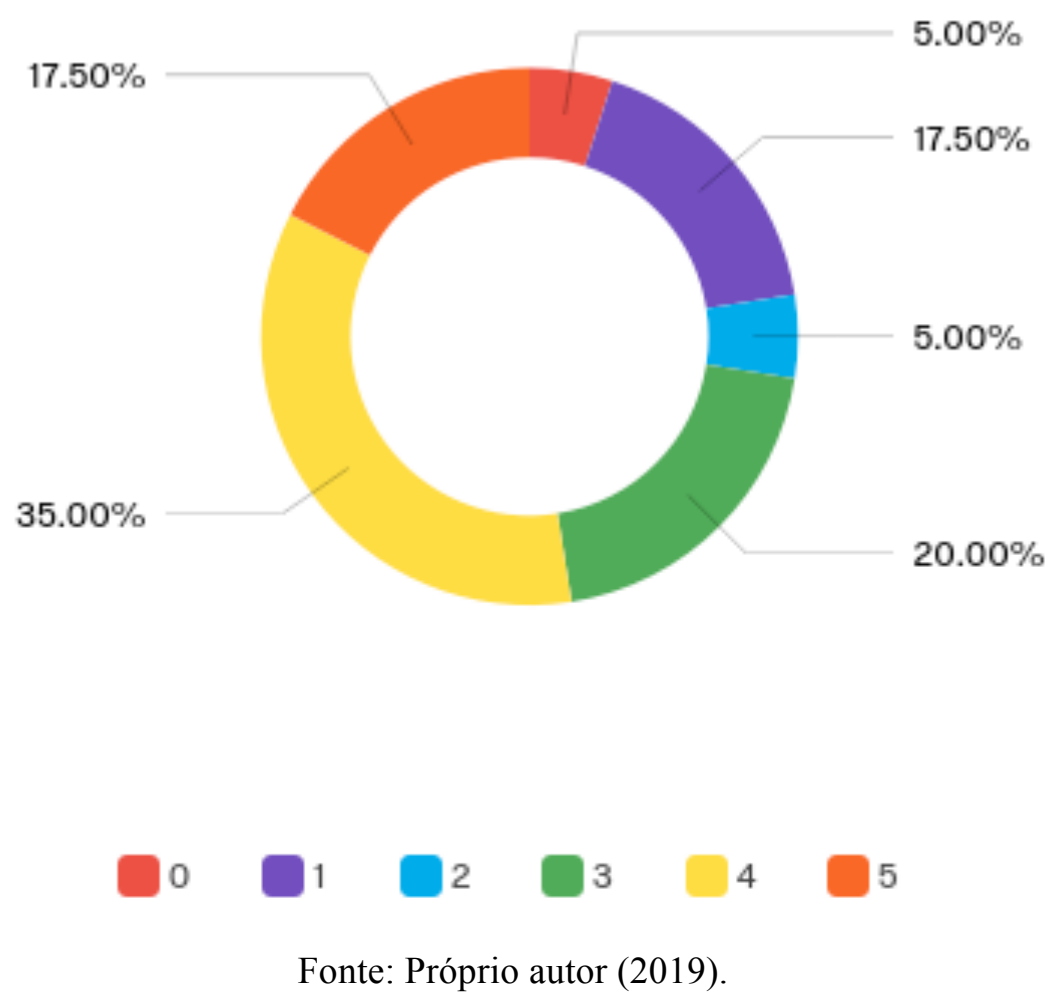

As quatros questões acima cujos resultados foram apresentados podem ser associadas a importância de uma boa relação entre líderes e liderados para a satisfação dos mesmos, fator atrelado a prática da inteligência social. As primeiras 
questões avaliaram a capacidade do líder em gerir pessoas e em seguida, se a relação entre liderados e líderes era boa. Ambas alcançaram resultados positivos. As próximas questões analisaram se a boa relação entre eles afeta o rendimento dos pesquisados na empresa, e em seguida, o quanto o liderado acredita que a forma como o líder interage interfere no seu dia a dia e no seu desenvolvimento profissional, obtendo também resultados semelhantes e positivos.

Com essas respostas, foi possível associar a forma como o líder utiliza a inteligência emocional e social com o desenvolvimento profissional dos seus liderados. Assim como foi afirmado pelos autores Quinn et al. (2015) que afirmam é importante que os líderes se importem com a sua saúde mental e social para a criação de um ambiente de trabalho coeso, com funcionários engajados. 


\section{Conclusão}

Acredita-se que o estudo cumpriu seu objetivo central de investigar a percepção dos liderados sobre a prática da inteligência emocional e social de seus líderes. Na seção voltada ao referencial teórico foram apresentados, dentre outros, conceitos relacionados à importância do uso dessas inteligências nas organizações.

Houve também uma pesquisa de campo via aplicação de um questionário, o via Qualtrics, que contou 29 perguntas, que foram respondidas por 40 liderados avaliando sua percepção em relação a inteligência emocional e social dos líderes e o impacto delas em seu trabalho. Como principais resultados da pesquisa de campo, pode-se dizer que a prática da inteligência emocional e social pelos líderes da organização são percebidas e afetam os liderados, de alguma forma. Segundo a visão dos liderados, as práticas voltadas para inteligência emocional e social pesquisadas geram impacto, como resumido a seguir:

- $73,5 \%$ acreditam que a forma como o líder interage com os liderados impacta, pele menos, de forma considerável a rotina de trabalho dos seus liderados.

- $65 \%$ acreditam tota ou parcialmente que o seu rendimento na empresa está atrelado a relação entre líderes e liderados.

- $60 \%$ afirmaram que os feedbacks costumam motivar os liderados no ambiente de trabalho

- $100 \%$ dos participantes que acreditam que os líderes que descontam os problemas pessoais no ambiente de trabalho, tem impacto negativo na atuação dos liderados.

- Dos liderados que afirmaram que seus líderes são empáticos, $82,61 \%$ acreditam que essa empatia melhora o seu rendimento no trabalho

- Dos liderados que afirmaram que os líderes não são empáticos, $80 \%$ acreditam que a falta de empatia afeta o rendimento deles na 
empresa.

- $65 \%$ dos participantes acreditam total ou parcialmente que o seu rendimento na empresa está atrelado a sua relação com seu líder.

Tendo como objetivo principal do trabalho compreender a forma como a prática da inteligência emocional e social afeta a relação entre líderes e liderados de uma organização, pode-se concluir que ele foi atingido. A partir do estudo de caso na Litografia Valença, foi possível relacionar a prática da inteligência emocional e social por parte dos líderes com a criação de um ambiente organizacional harmônico e positivo, na visão dos liderados. Além disso, foi possível perceber como essas inteligências são percebidas pelos liderados, e se essa percepção impactano dia a dia de trabalho.

\subsection{Recomendações para novos estudos}

O presente estudo pode servir como base para outros estudos dentro da própria empresa, com o intuito de avaliar, com mais detalhes, a relação entre cada líder eos seus liderados, ou seja, é aconselhável que um próximo estudo identifique a área de cada liderança. Além disso, outros setores da empresa podem ser estudados e avaliados da mesma forma. Para aprofundar mais o assunto, podem ser usados outros métodos de coleta de dados, como por exemplo, entrevistas com os liderados.

O estudo pode estimular também a aplicação de pesquisas semelhantes em outras organizações que se importam com a inteligência social e emocional e seus possíveis impactos na organização. 


\section{REFERÊNCIAS BIBLIOGRÁFICAS}

BRADBERRY, Travis. Desenvolva a sua inteligência emocional. Rio de janeiro: Sextante, 2007.

BOYATZIS, R.; MCKEE, A. O poder da liderança emocional. Rio de Janeiro: Campus Elsevier, 2006.

GOLEMAN, D. Inteligência emocional, a teoria revolucionária que redefine o que é ser inteligente. Rio de Janeiro: Objetiva, 1996. 2006. Inteligência Social, o poder das relações humana. São Paulo: Campus,

JUNQUEIRA, Fernanda Campos. Et al. A Importância da Inteligência Emocional na Atuação de um Líder. 2011. Disponível em:

$<$ https://www.aedb.br/seget/arquivos/artigos11/38814405.pdf. $>$ Acesso em: 22 abr. 2019.

Litografia Valença. Disponível em: <http://lvalenca.com.br/.> Acesso em: 08 abr. 2019.

QUIN, Robert. et al. Competências Gerenciais - A abordagem de valores concorrentes na gestão. Rio de janeiro: Campus, 2015.

SILVA, Beatris Maria Monteiro da. et al. A Inteligência Emocional na Liderança e Sua Relação com a Melhoria da Comunicação Interpessoal nas Organizações: Estado do Conhecimento no Seget. 2014. Disponível em:

$<$ https://www.aedb.br/seget/arquivos/artigos14/1620409.pdf. $>$ Acesso: 26 abr. 2019.

VERGARA, S. C. Projetos e relatórios de pesquisa em administração. São Paulo, 2009. São Paulo: Atlas S.A., 1998. 


\subsubsection{Apêndice 1:}

Prezado participante, Esta é uma breve pesquisa sobre a relação entre líderes e liderados dentro de uma organização, com finalidade meramente acadêmica e para fins de conclusão de dissertação. As informações são sigilosas e os remetentes não serão identificados. Para contribuir, basta prosseguir abaixo e responder até o final. Em caso de dúvidas, segue meu email: nicollebbrasil@,hotmail.com. Muito obrigada! Nicolle Brasil PUC-RIO

1 Qual é a sua idade?

- $\quad$ Entre 20 e 25

- $\quad$ Entre 26 e 35

- $\quad$ Entre 36 e 45

- $\quad$ Entre 46 a 55

- 55 ou mais

2 Sexo

- Feminino

- Masculino

- Não quero identificar 
3 Quanto tempo você tem de empresa?

- Até 1 ano

- Entre 1 ano e 5 anos

- Entre 5 anos e 10 anos

- Entre 10 anos e 15 anos

- 15 anos ou mais

4 Você considera que seu líder é preocupado em manter a equipe motivada e um ambiente de trabalho saudável?

- Sempre

- Quase sempre

- Quase nunca

- Nunca

5 Você considera seu líder um líder autoritário, ou seja, costuma não ouvir opiniões diferentes da sua de forma receptiva?

- Sempre

- Quase sempre

- Quase nunca

- $\quad$ nunca

6 O seu líder se preocupa em conhecer as dificuldades e limitações de cada membro e busca desenvolvê-las?

- Sempre

- Quase sempre

- Quase nunca

- Nunca 
7 O seu líder apresenta uma comunicação transparente, articulada e motivadora?

- Sempre

- Quase sempre

- Quase nunca

- Nunca

8 O seu líder dá feedbacks construtivos?

- Sempre

- Quase sempre

- Quase nunca

- Nunca

9 De 0 a 5 com que frequência você recebe feedbacks mensalmente.

- 0

- 1

- 2

- 3

- 4

- 5

10 De 0 a 5, qual é o nível de satisfação com os feedbacks.

- 1

- 2

- 3

- 4

- 5 
11 Justifique o item acima.

- Os feedbacks costumam me motivar

- Os feedbacks costumam me frustrar

- Nem sempre entendo o motivo do feedback

- Para mim os feedbacks são indiferentes

- Outros

12 Qual é a sua opinião sobre a capacidade do seu líder em gerir pessoas?

- Muito boa

- Boa

- Ruim

- Muito ruim

13 O seu líder, as vezes, desconta seus problemas pessoais no ambiente de trabalho?

- Sempre

- Quase sempre

- Quase nunca

- Nunca

\section{Apresentar esta pergunta:}

If O seu líder, as vezes, desconta seus problemas pessoais no ambiente de trabalho? $=$ Sempre 
14 Se sim, de 0 a 5 , quanto você acredita que esses problemas pessoais podem te afetar como liderado.

- 0

- 1

- 2

- 3

- 4

- 5

\section{Apresentar esta pergunta: \\ If O seu líder, as vezes, desconta seus problemas pessoais no ambiente de trabalho? = Quase sempre}

15 Se sim, de 0 a 5, quanto você acredita que esses problemas pessoais podem te afetar como liderado.

- 0

- 1

- 2

- 3

- 4

- 5

16 Você acredita que os líderes sabem seus próprios pontos fracos e procuram melhorá-los?

- Sempre

- Quase sempre

- Quase nunca

- Nunca 
$17 \mathrm{O}$ seu líder deixa que suas próprias emoções afetem negativamente assuntos ligados a empresa, por exemplo, após uma reunião estressante desconta na sua equipe?

- Sempre

- Quase sempre

- Quase nunca

- Nunca

18 Como você acha que os líderes lidam com os problemas do dia a dia?

- Costumam encarar o desafio de frente

- Costumam depositar em outras pessoas

- Costumam perder tempo se estressando pela causa do problema

- Costumam postergar a solução do problema

19 Você considera o seu líder uma pessoa fechada, ou seja, procura não criar uma intimidade maior com os seus liderados, não permitindo que eles o conheça realmente?

- Sempre

- Quase sempre

- Quase nunca

- Nunca

20 Seu líder é uma pessoa com empatia, ou seja, capaz de sentir e entender as emoções dos membros da equipe e procura ajudá-los?

- Sim, ele é capaz de sentir, entender e ajudar

- Sim, ele é capaz de sentir, mas nem sempre entender ou ajudar

- Não, ele não costuma sentir, entender e ajudar 
Apresentar esta pergunta:

If Seu líder é uma pessoa com empatia, ou seja, capaz de sentir e entender as emoções dos membros da... = Sim, ele é capaz de sentir, entender e ajudar

21 Você acredita que a empatia do seu líder melhora o seu rendimento na empresa?

- Concordo

- Indiferente

- Discordo

Apresentar esta pergunta:

If Seu líder é uma pessoa com empatia, ou seja, capaz de sentir e entender as emoções dos membros da... = Não, ele não costuma sentir, entender e ajudar

22 Você acredita que a falta de empatia do seu líder afeta o seu rendimento na empresa?

- Concordo

- Indiferente

- Discordo

23 O líder sabe a forma adequada de se comportar diante de alguma determinada situação, podendo ser diferente do que ele está acostumado?

- Sempre

- Quase sempre

- Quase nunca

- Nunca 
24 Você acredita que o líder se importa com as necessidades dos seus subordinados?

- Sempre

- Quase sempre

- Quase nunca

- Nunca

25 Você acredita que esse fator é importante para a criação de uma boa relação no ambiente de trabalho?

- Concordo totalmente

- Concordo

- Discordo

- Discordo totalmente

26 Como é a sua relação com o seu líder?

- Ótima

- Boa

- Difícil

- Muito difícil

27 Você acredita que a sua relação com o líder afeta seu rendimento na empresa?

- Concordo totalmente

- Concordo

- Discordo

- Discordo totalmente 
28 De 0 a 5, quanto você acredita que a forma como o líder interage com você interfere no seu dia a dia e desenvolvimento profissional?

- 0

- 1

- 2

- 3

- 4

- 5

29 Você se sente confortável em dar feedbacks ao seu líder, dizendo à ele o que incomoda ou agrada e a forma como ele pode melhorar?

- Sempre

- Quase sempre

- Quase nunca

- Nunca 